\title{
波浪荷重をう外引海底粘土地盤の沈下解析 \\ Shakedown Analysis of Clay Seabed under Wave Induced Loading
}

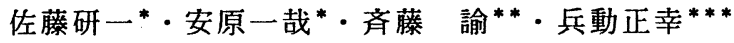 \\ Ken-ichi Sato, Kazuya Yasuhara, Satoshi Saito and Masayuki Hyodo
}

\begin{abstract}
This paper describes a method of applying the results of cyclic triaxial tests on undisturbed samples of a marine clay to predict the settlement of a breakwater. The stresses and strains beneath the structure are determined using a finite element analysis allowing the determination of shear deformations under undrained cyclic loading and settlements due to post-cyclic volumetric changes. The results of numerical analysis indicate that the cyclic-induced settlements of a lightweight breakwater on seabed clay are mainly influenced by the kind of breakwater, the direction of wave action and the base width of breakwater.

KEY WORDS : Wave load/Clay seabed/Shakedown Analysis/Breakwater
\end{abstract}

\section{1.はじめに}

近年、海上空港の建設や首都圈を初めとして港湾の埋め立て有効利用するウォーターフロントの開発が盛んに行 われるようになってきた。これらの構造物うち、防波堤のような沿岸構造物は波浪により繰返し荷重を受けるこ とになる。この時防波堤下の海底粘土地盤もこの防波堤を媒体とする相互作用により、繰り返し応力を受ける。 したがって、台風等の波浪の厳しい条件下では地盤が受ける繰返し応力も大きくなり、このため防波堤は沈下し たり、不安定になり、場合によっては破壊することす考えられる。このような現象は、土の非排水繰返しせん断 と繰返しせん断により蓄積した過剩間隙水圧の消散との 2 つの現象の重ね合わさることにより生じると考えられ

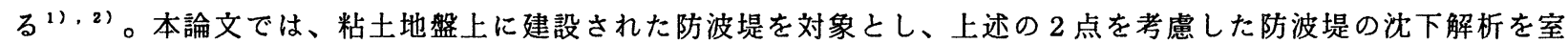
内試験の結果と有限要素弾性解析を組み合わせることにより数値実験を行い、その結果の考察を行った。

\section{2. 波浪荷重を受ける防波堤の沈下解析手法}

防波堤の沈下解析における評価法 ${ }^{2)}$ は表- 1 に示す通りである。防波堤下の海底粘土地盤は、波の作用の連続 性を考えると、防波堤との相互作用により非排水繰返し荷重によるひずみが生じるとともに、地盤内に過剩間隙 水圧が累積することになる。また、この過剩間隙水圧は、波が平静時には消散するためにこれに伴う沈下す生じ

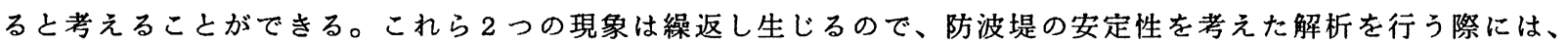
これらの現象を考虑に入れる必要があると思われる。著者ら ${ }^{3)}$ ，4)，5）、8) は、これまでに非排水繰返し三軸試験結 果を用い、繰返し応力下の土のひずみ量と間隙水圧の発生量の予測を提案し、その適用例を示してきた。そこで 本論文では、室内試験によって海底より採取された不摫乱試料を用いた非排水繰返し三軸試験を行い、この試験 結果 ${ }^{7}$ ，8) から任意の繰返し応力と繰返し回数下で生じるのひずみ量と過 剩間隙水圧の発生量の予測を行う定式化を行った。次いで、対象となる 地盤の状態と、解析対象海面の波の情報から、防波堤に作用する波圧を 合田の式 ${ }^{9}$ により求め、次にこれらのデー夕を用いて有限要素弾性解析 の結果より求められる各要素の最大主応力を波と防波堤の相互作用によ って地盤内に生じる繰返し応力と考えると、非排水繰返し荷重によるひ ずみ量と過剩間隙水圧の発生量の予測式を用いることにより任意の波の 繰返し回数時における最大主応力の作用方向に生じるひずみと過剩間隙 水圧を求めることが可能となる。また、過剩間隙水圧の消散によって生 じる再圧密に伴うひずみ量として安原ら ${ }^{10)}$ が行った室内試験の結果から の予測式を用いて評価し、このひずみ量より沈下量を求めた。このよう な方法を用い、非排水繰返し荷重による沈下量と過剩間隙水圧の消散に よる沈下量を重ね合わせて波浪荷重を受ける防波堤下の海底粘土地盤の 全沈下量とした。

3. 波浪荷重を受ける軟弱地盤の沈下と安定性の評価手法 $3-1$ 変形予测モデル

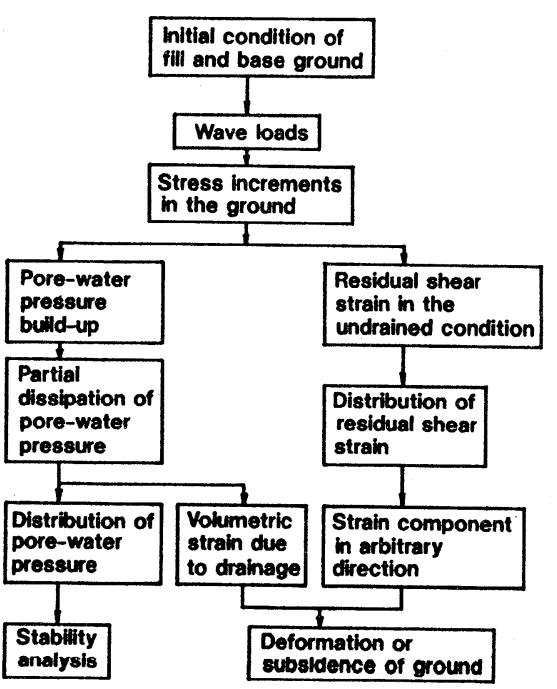

表-1 防波堤の沈下解析の評価法 ${ }^{31}$

(Hyodo et a1.,1988)

兵動ら ${ }^{71.8)}$ は、不覧乱粘土の繰返し三軸試験に基づいて、繰返し荷重

* 正会員 茨城大学工学部都市システム工学科（316 日立市中成沢町 4-12-1）、**非会員 神奈川県、 *** 正会員 山口大学工学部社会建設工学科 
を受ける粘土の変形と間隙水圧の定量的な評価法を提案した。図ー 1 にこれら 三軸試験の結果から不摜乱粘土の変形と間隙水圧の定量的な評価を行う際のフ ローチャートを示す。予测手法の詳細は別途示している ${ }^{1)}$ ７，8)。 $3-2$ 地般内要䒺の鈆直ひずみの評価 ${ }^{1) 、 3)}$

室内の繰り返し三軸試験では、周知のように側圧 $\sigma_{3}$ が一定で軸圧 $\sigma_{1}$ のみが 変化するが、実際の地盤においては繰り返し応力によって主応力が常に変動す る。また、実験においては軸対称であるのに対し、解析では平面ひずみ状態の 結果であることから、この関係を対応づけるために、実験および解析共に45度 面の最大せん断応力 $\tau_{\mathrm{max}}$ の変動量を取り出し対応させることとした。これを用 いれば、三軸試験における軸応力、軸ひずみを最大せん断応力及び最大せん断 ひずみに変換を行うと非排水条件下では以下のようになる。

$$
\sigma_{a}=2 \tau_{\text {max }} \quad \varepsilon_{a}=(4 / 3) \gamma_{\max } \quad \cdots \cdots \cdot(1)
$$

以上のような応力とひずみの対応を行うと、解析により所定の波浪荷重など の綝り返し作用による地盤内のひずみとして最大せん断ひずみが求められるこ とになる。しかし、現実問題は波浪荷重などによる地盤の沈下量や水平方向へ の変形量などを評価することが多い。そこで、最大せん断ひずみを用いて、任 意の方向の垂直、最大せん断ひずみを求める方法を検討した。図 - 2 に実験と解析のひずみ状態を表すモールのひずみ円を示して いる。今、非排水状態を考えているので、実験では軸対称の条件 で $\varepsilon_{1}+2 \varepsilon_{3}=0$ 、解析では平面ひずみ条件で $\varepsilon_{1}+\varepsilon_{3}=0$ が保たれて いる。従って、これらのモールのひずみ円は図のような形となる。 解析においては、 $\varepsilon_{1}=\gamma_{\mathrm{max}}$ となって最大主ひずみが明かとなり、 さらに主ひずみ(応力)軸からの回転角 $\alpha$ が与えられればいずれの ひずみ成分す計算することが可能である。主ひずみ軸とのなす角 度を $\alpha$ とすると、鉛直ひずみ $\varepsilon$ 、と水平ひずみ $\varepsilon_{\mathrm{n}}$ は、

$$
\varepsilon_{\mathrm{v}}=\varepsilon_{1} \cos 2 \alpha \quad \varepsilon_{\mathrm{h}}=\varepsilon_{3}
$$

により求めることが出来る。したがって、地中各要素において

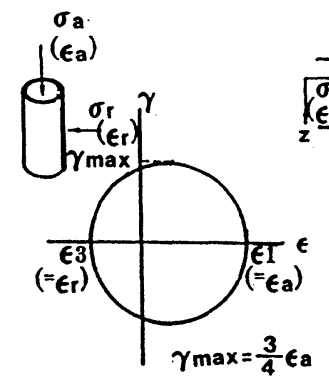

Triaxial test

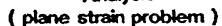

図-2 実験と解析のひずみの状態 ${ }^{3)}$ 鈆直ひずみと水平ひずみを求めることによって、非排水条件における沈下量 と側方変位量を求めることが出来る。

\section{$3-3$ 発生間隙水厓の消散による沈下量の評価法 ${ }^{10)}$}

非排水条件で、飽和地盤が繰り返し荷重を受けると、地盤内には過剩間隙 水圧が発生する。この間隙水圧の時間的変化を非排水繰り返し三軸試験の結 果より、次のようにして予測した。

まず、図ー 1 に示した $\mathrm{p}-\mathrm{q}$ 平面上で、繰り返し荷重をN回受けたときの間隙 水圧は次の式のように与えられる。

$$
u_{\mathrm{p}}=\mathrm{p}_{\mathrm{c}}{ }^{\prime}+\left(\mathrm{q}_{\mathrm{c} y \mathrm{c}}-\mathrm{q}_{\mathrm{s}}\right) / 3-\mathrm{q}_{\mathrm{c} y \mathrm{c}} / \eta_{\mathrm{s}}
$$

このように、軟着堤の施工された海底地盤内では過剩間剩水圧が発生する。 しかし、この地盤内に発生した間隙水圧は、波浪がおさまった後にゆっくり図ー 3 と消散することになる。この間隙水圧の消散によって地盤は再圧密され、沈下を 起こすと考えられ、波浪による海底地盤の沈下量を評価する際には、この間隙水 圧による沈下の影響を考慮する必要がある。この際圧密沈下によって生じるひず みは、次式で計算される ${ }^{10)}$ 。

$$
\varepsilon_{\vee r}=\alpha \cdot\left\{C_{r} /\left(1 / e_{0}\right)\right\} \cdot \log \left\{\left(1 /\left(1-u_{p} / p_{e}\right)\right\}\right.
$$

ここで、有明粘土の室内試験の結果を用いて、 $\alpha$ : 実験定数、 $\mathrm{C}_{\mathrm{r}}$ : 再圧縮係数で ある。また、 $\mathrm{e}_{0}$ は供試体の初期間隙比である。

\section{3-4 全沈下量の評価法}

有限要素解析結果と上述の 2 つの沈下量の評価法にしたがってそれぞれのひず み量を算定し、足し合わせた波と防波堤の相互作用によって生じる海底粘土地盤 の沈下量の計算を行った。

\section{4. 波浪荷重を受ける防波堤の弾性解析}

4-1 波浪荷重を受ける防波堤の概要 図一 3 に今回解析の対称とした防波堤と地 盤の概要を示す。基礎地盤は層厚 $20 \mathrm{~m}$ の一様な粘土で構成されていると仮定した。

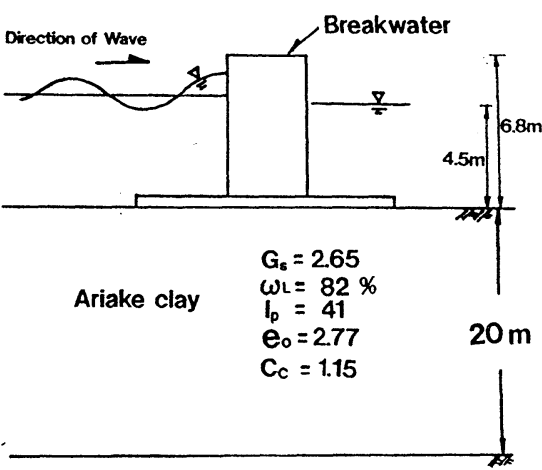

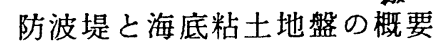
16
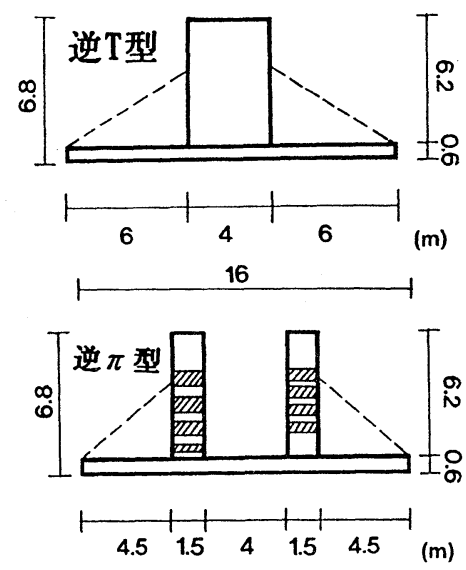

四一 4 解析に用いた防波堤の 形状 


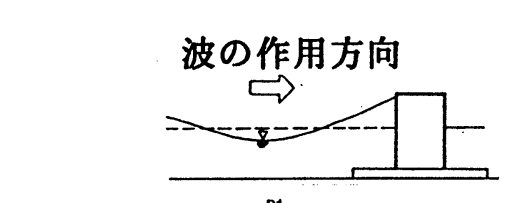

押し波作用時

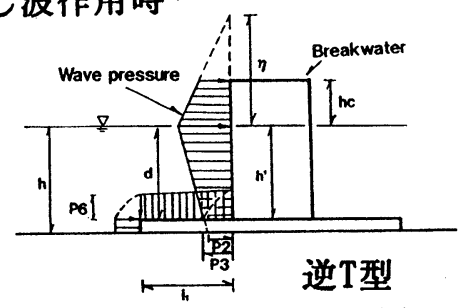

波の作用方向

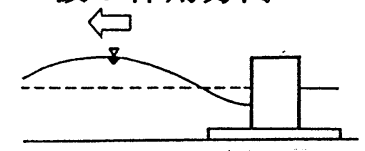

引き波作用時

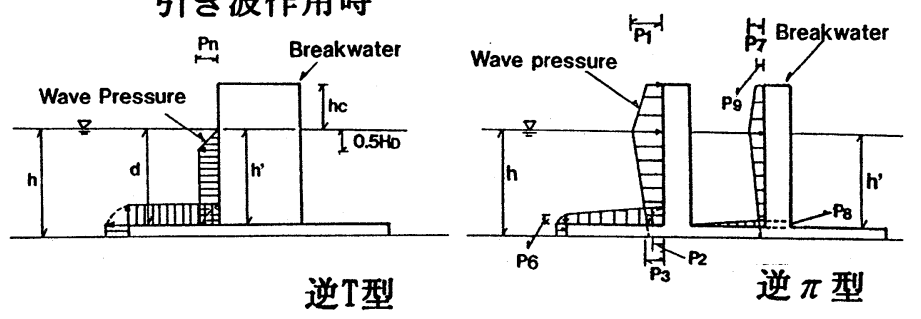

図一 5 防波堤に作用する波圧分布"

また、防波堤は幅 $16 \mathrm{~m}$ ，高さ $6.8 \mathrm{~m}$ の大きさを標準的な防 波堤とした。また、粘土地盤の物理的性質も図中に示し ている。今回解析対象とした防波堤は、軟弱地盤着底式 防波堤 (軟着堤) ${ }^{11}$ 之呼ばれ、地盤改良をしない軟弱 地盤上に軽量のケーソンを直接設置する方式のものであ る。また波の特性は、熊本港の有義波のデー夕（周期: $5.44(\mathrm{~s})$ 、波長: $39(\mathrm{~m}))$ を用い、波数は各波高 $(0.5 \sim 5$. $0 \mathrm{~m}$ まて $0.5 \mathrm{~m}$ お $)$ の波浪が $6 、 12 、 24 、 48$ 時間続くと考元、各時間に相当 する波数を計算して解析を行った。

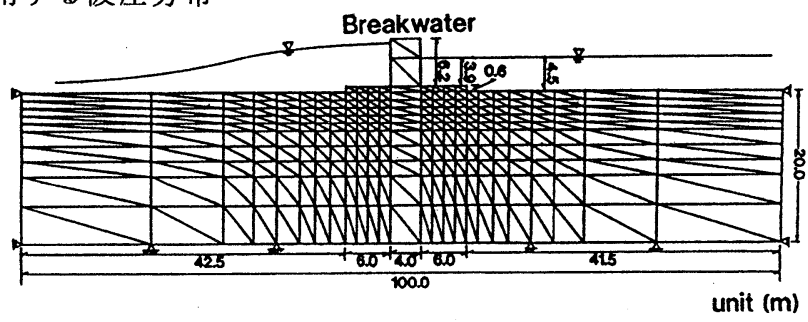

図一 4 に今回解析の用いた逆 $\mathrm{T}$ 型と逆 $\pi$ 型の防波堤の形状と大きさ を示す。また、図一 5 にその波圧分布を示す。逆 T形の防波堤は、波 をふせぐ鉛直壁部と地盤とが接触し付着力を発揮する堤版部から構成 されている。また逆 $\pi$ 型は、防波堤前部壁面に作用する波圧を軽減す るために、開口部があり波圧の軽減が施されているが、防波堤中央部 にも波が入るために、後部壁にす波圧が生じる点が逆 $\mathrm{T}$ 型と異なる。 防波堤自身の自重を軽減するためにこのような形状波高押し波 図ー6 解析に用いたモデル 表 -2 弾性解析に使用した入力定数 が考えられた。これらの防波堤に生じる波圧分布は、 防波堤壁面に波の峰があるときと波の谷があるとき の 2 つの場合について考元、合田の式”により求め た。

\section{4-2 解析条件}

解析は、有限要素法による地盤解析用プログラム 12)を用いて、非排水状態及び平面ひずみ状態の弾性 解析を行った。図一6に解析に用いたモデルを示し ている。粘土地盤厚さ $20 \mathrm{~m} 、$ 地盤幅を $100 \mathrm{~m}$ とし、地盤 の解析モデルは要素数 500 、節点数 286 の三角形要素と した。このモデルの上に前記の各形状の防波堤を想

\begin{tabular}{|c|c|c|}
\hline & 海底粘土地盤 & 構造物(軟着堤) \\
\hline 水平弹性係数 $\mathrm{E}_{\mathrm{n}}$ & $357 \mathrm{kPa}$ & $2.8 \times 10^{\prime} \mathrm{kPa}$ \\
\hline 鈆直弹性係数 $\mathrm{E}_{\mathrm{v}}$ & $357 \mathrm{kPa}$ & $2.8 \times 10^{\gamma} \mathrm{kPa}$ \\
\hline 水平ポアソン比 $\nu_{\mathrm{na}}$ & 0.25 & 0.2 \\
\hline 鈶直ポアソン比 $\nu \mathrm{va}$ & 0.25 & 0.2 \\
\hline $\mathrm{G}=\mathrm{E} /(2(1+\nu))$ & $143 \mathrm{kPa}$ & $1.17 \times 10^{7} \mathrm{kPa}$ \\
\hline
\end{tabular}

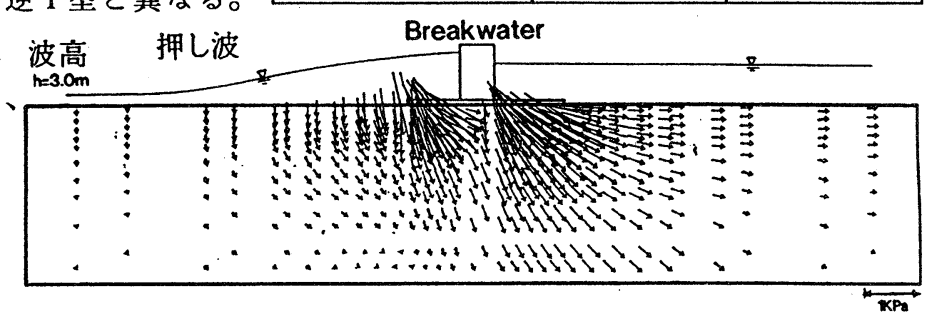

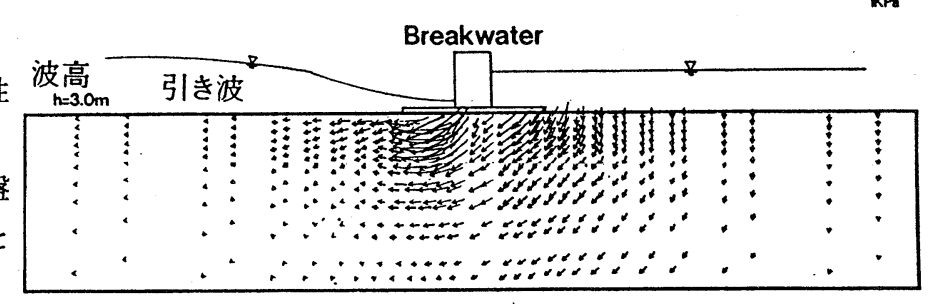
定した。表一 2 に解析に使用した構造物（防波堤）図ー 7 地盤内に発生する最大主応力の大きさとその方向 と地盤（粘土）の弾性係数、ポアソン比を示す。海底粘土地盤の弾性係数に ついては、三軸試験の結果の応力ひずみ曲線を用い、初期接線勾配を用いて 算定した。このようにして求められるパラメー夕を用いて弾性解析を行い、 地盤内応力（最大主応力）とその方向を求めた。解析では防波堤自身の自重 を考慮せずに解析を行っている。また、数值実験は波の作用方向、波数、波 高、防波堤の形状をパラメータとして行い、その計算結果から、それぞれ沈 下量、発生間隙水圧に及ぼす影響について考察をした。

\section{5. 解析結果および考察}

5-1 非排水繰返しによって生じる沈下量

(a)波の作用方向が防波堤の沈下量に及ぼす影響 解析では波の振幅の特 性を取り込むことを考元、波が防波堤壁面に作用する波圧の計算時において、

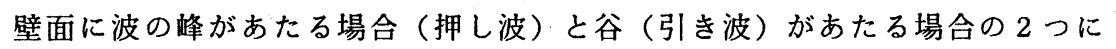
分けておこない、それぞれの波が連続的に防波堤にあたると仮定して沈下量

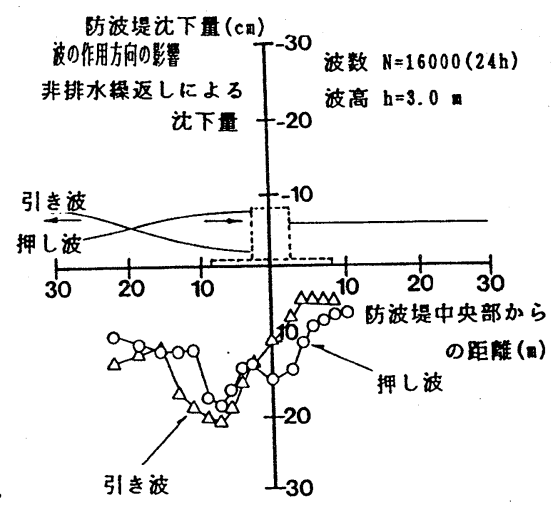

図-8 波の作用方向が沈下量に 及ぼす影響 
の計算を行った。図ー7に弾性解 析によって求められる海底粘土地 盤内に発生する最大主応力の大き さと方向を示す。これらの図より、 最大主応力は防波堤の前端部と後 端部に集中していることがわかる。 また、押し波と引き波では、最大 主応力の大きさが異なり、その方 向も反転していることがわかる。 このことは、実際の地盤内ではこ
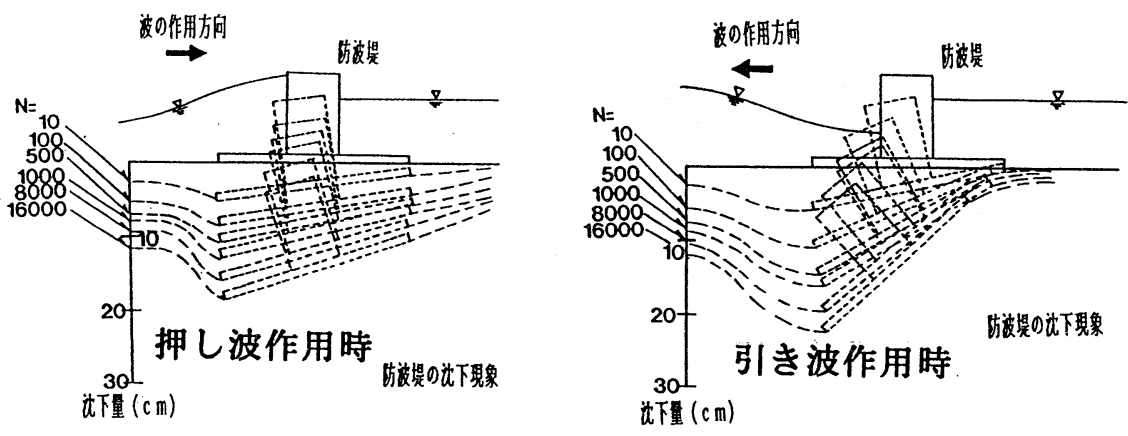
のように主応力の方向と大きさが複雑に入れ替ると思われ、防波堤の安 定性を考える際には、この影響を考える必要があることを示唆している。 図一 8 には防波堤に作用する波の方向（波数：N=16000(24h)、波高 : h= $3.0 \mathrm{~m})$ が非排水繰返しせん断によって生じる沈下量に及ぼす影響を示し た。この結果では、波の作用方向の影響はさほど見られない。一方、押 し波時と引き波時の波の繰返し回数によって防波堤が沈下していく様子 を模式的に示した図ー9によれば、押し波時では、波の繰返し回数の增 加に伴って防波堤前端部が倒れ込み、防波堤全体が沈むように沈下して おり、引き波時では、繰返し回数の増加とともに防波堤後端部を中心と して、防波堤前端部がかなり大きく沈下しており、両者は異なった沈下 形態を示すことがわかる。これは、地盤内に発生する最大主応力の方向 と大きさが波の作用方向によって異なることによる影響と考えられる。

(b) 防波堤の形状が防波堤の沈下量に及ぼす影響 今回の解析では、 防波堤の形状が防波堤の安定性に及ぼす影響について調べた。

図ー 10 に逆 T型と逆 $\pi$ 型の 2 タイプにおける、防波堤に押し波（波 数: $\mathrm{N}=16000(24 \mathrm{~h})$ 、波高: $\mathrm{h}=3.0 \mathrm{~m})$ が作用する場合に非排水繰返し荷重 によって生じる沈下量を比較している。この図から、防波堤の形状によ り沈下形態が異なり、逆 $\mathrm{T}$ 型では防波堤前端部が沈下するのに対し、逆 $\pi$ 型では防波堤中央部から後端部にかけての沈下が生じている。これは、 逆 $\pi$ 型が後壁部でも波圧を受けているためと思われる。

(c) 防波堤底部の幅(B)が防波堤沈下量に及ぼす影響 防波堤底部の 幅 (B)が防波堤の安定性に及ぼす影響を調べるために、防波堤底部の幅を $\mathrm{B}=13 \mathrm{~m}, \mathrm{~B}=16 \mathrm{~m}$ の 2 種類を考えて解析を行った。図一 11 に各底部幅の防波 堤に押し波（波数: $\mathrm{N}=16000(24 \mathrm{~h}$ )、波高: $\mathrm{h}=3.0 \mathrm{~m}$ ) が作用する場合 に、非排水繰返しによって生じる沈下量に及ぼす影響を示す。この 図から、底部幅が狭い方 $(B=13 m)$ は、防波堤中央部に急激な沈下がみ られるが、底部幅が広い方 $(B=16 \mathrm{~m})$ では、防波堤前端部に沈下の片寄 りはあるあのの全体に均等に沈下していることがわかる。このこと から、防波堤の底部の幅が広い方が安定性が良いと言える。

(d) 波の繰返し回数（波数）が防波堤の沈下量に及ぼす影響 一般的に波浪は、不規則な波高をむってランダムに防波堤に作用し、 またその回数（波数）むまちまちである。このような波の特性を簡 単に取り扱うために、波高の高さを固定し、かつ波数は有義波のデ 一タを用い、その周期からそれぞれ任意の時間での波数の計算を行 い解析に用いた。逆 $\mathrm{T}$ 型の標準防波堤に波高 $\mathrm{h}=3.0 \mathrm{~m}$ の押し波および 引き波が $\mathrm{N}=10,100,500,1000,8000,16000$ 回あたった時の非排水繰返 しに伴う沈下量をそれぞれ、図ー1 2 に示す。これらの結果から、 地盤の沈下量は、波の繰返し回数に影響され、押し波、引き波とも 波の作用回数が増加するととすに沈下が進んで行く様子がわかる。 5-2 過剩間隙水圧の消散によって生じる再圧密にとむなう沈下量

図一 13 に $\mathrm{h}=3.0 \mathrm{~m}$ の押し波と引き波が逆 $\mathrm{T}$ 型防波堤にそれぞれN= 4000,16000回作用したときに海底粘土地盤内に発生した過剩間隙水 図 -11

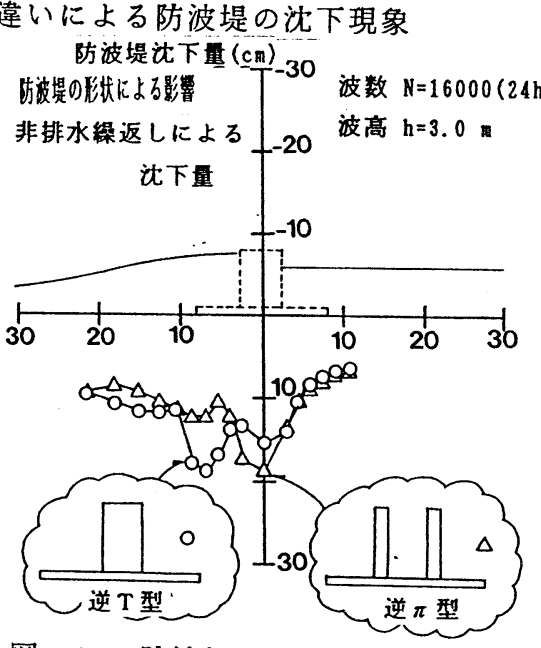

図-10 防波堤の形状が沈下量に 及ぼす影響

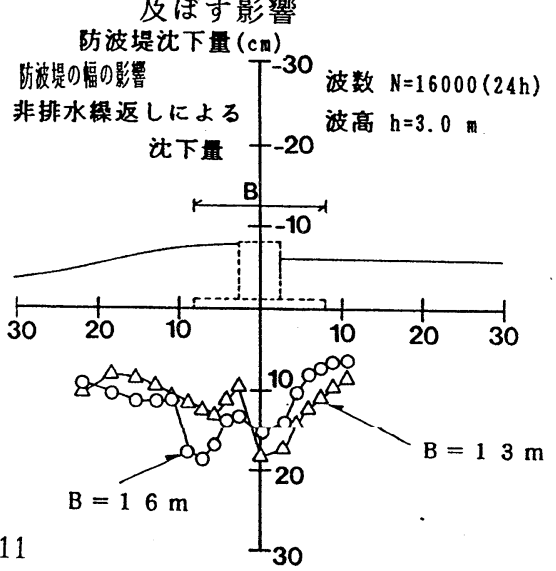

防波堤底部の幅 (B)が沈下量に及ぼす影響
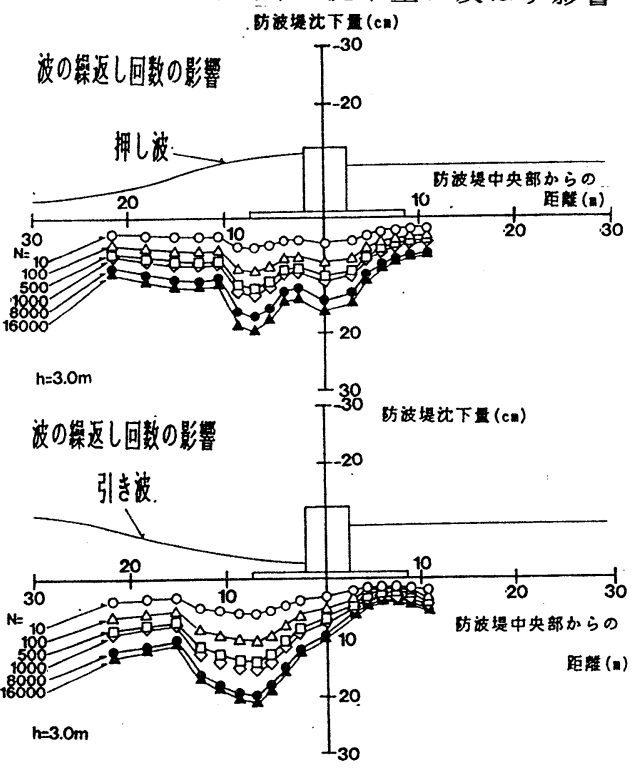

図-12 波の繰返し回数が防波堤沈下量に 及ぼす影響 


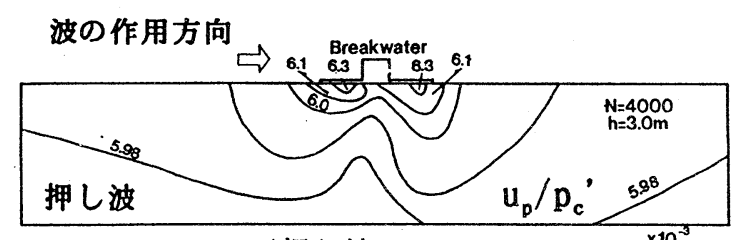

波の作用方向（押し波: $N=4000, h=3 m$ ） $\times 10^{-3}$

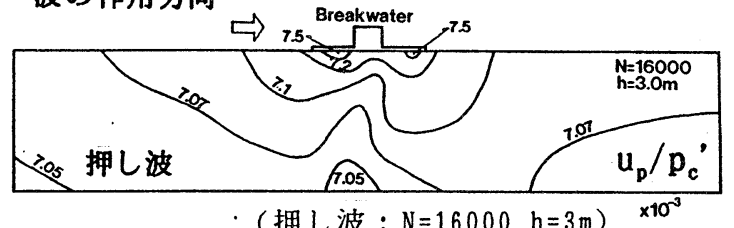

（押し波： $\mathrm{N}=16000, \mathrm{~h}=3 \mathrm{~m}$ )

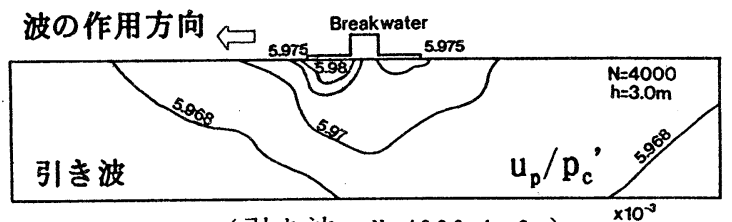

(引き波 : $\mathrm{N}=4000, \mathrm{~h}=3 \mathrm{~m}$ ) 波の作用方向 $\leftrightarrow$ Breakwater

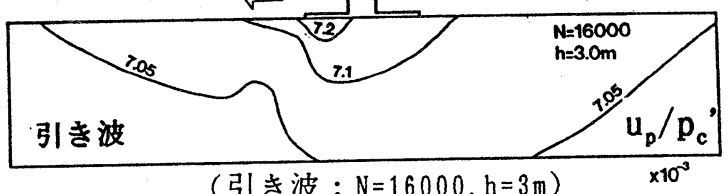

（引き波 : $\mathrm{N}=16000, \mathrm{~h}=3 \mathrm{~m}$ ）

圧の分布を示す。押し波が作用した場合は、防波堤の前端部及び後端 部最大の過剩間隙水圧の発生がみられ、徐々に地盤全体に広がって行 く様子がうかがえる。引き波作用時の場合は発生する間隙水圧が同じ 回数では、小さくなっており、防波堤前端部にその発生量が大きくな っていることがわかる。さらに詳細に調べるために波の高さが $3 \mathrm{~m} の$ 押 し波が作用した場合に防波堤底部（前端部、中央部、後端部）におけ る過剩間隙水圧の発生量と波数の関係を図ー14 に示す。この図より 防波堤底部の間隙水圧は、波の繰返し回数と共に増加し、その発生量 は、防波堤中央部よりも防波堤の前・後部に顕著に現れていることが わかる。次に、この防波堤底部（前端部、中央部、後端部）の発生間隙 水圧が海底粘土地盤内にどの様に伝達されいるかについて、防波堤に 押し波（波数： $\mathrm{N}=16000(24 \mathrm{~h}$ )、波高: $\mathrm{h}=3.0 \mathrm{~m}$ ) が作用する場合の発生 間隙水圧と深さの関係を図一 15 に示す。この図上り、発生間隙水圧 は深度が深くなるにつれて小さくなり、防波堤中央部よりも前・後端 部に顕著な発生がみられるが、防波堤の後端部は前端部よりす、防波 堤底部で発生した間隙水圧の深度による低下率が小さいことがわかる。 したがって防波堤下の地盤は非排水の繰返しに伴って、特に防波堤直 下部の地盤内に過㮃な間隙水圧が発生し、この間隙水圧の消散により 再圧密が生じて防波堤直下部に沈下が生じると考えられる。そこで、 各影響因子が過剩間隙水圧の消散に伴う沈下量に及ぼす影響について、 防波堤に押し波および引き波（波数：N=16000(24h)、波高 : $\mathrm{h}=3.0 \mathrm{~m}$ ) が作用する時の結果を以下に述べる。

(a)波の作用方向による影響 図一-16 に波の作用方向が過剩間隙水 圧の消散にとすなう沈下量に及ぼす影響について、沈下量を示す。こ れから、波の作用方向の影響が沈下量に顕著に現れており引き波では、 沈下量に場所による差がほとんどみられないが、押し波では間隙水圧 の発生の分布通りに防波堤前・後端部に沈下が起こっていることがわ かる。

(b)防波堤の形状による影響 図一 17 に逆 $\mathrm{T}$ 型と逆 $\pi$ 型の防波堤形 状の違いが過剩間隙水圧の消散にともなう沈下量に及ぼす影響につい て沈下量を示す。この図より、形状の違いによる影響はさほど見られ ないが、逆 $\mathrm{T}$ 型の方が逆 $\pi$ 型より前・後端部で沈下が顕著であるのに 対し、逆 $\pi$ 型では、防波堤壁部の開口部の影響により防波堤後部に沈 下が生じている。

(c)防波堤の幅の影響 図一 18 K 種類の防波堤底部の幅 $(B=13 \mathrm{~m}$ 、 $16 \mathrm{~m})$ の違いが過剩間隙水圧の消散にとむなう沈下量に及ぼす影響につ いて沈下量を示す。この結果から幅の広い方がわずかながら、防波堤 が地盤に繰り返し応力を伝える面積が広いため沈下量が少なくなって いることがわかる。このことは、発生間隙水圧の上昇量と繰返し応力 の大きさが表稟一体の関係を示していることから考えると、防波堤の 幅を広げることにより、地盤内に均等に波圧による繰返し応力を伝え

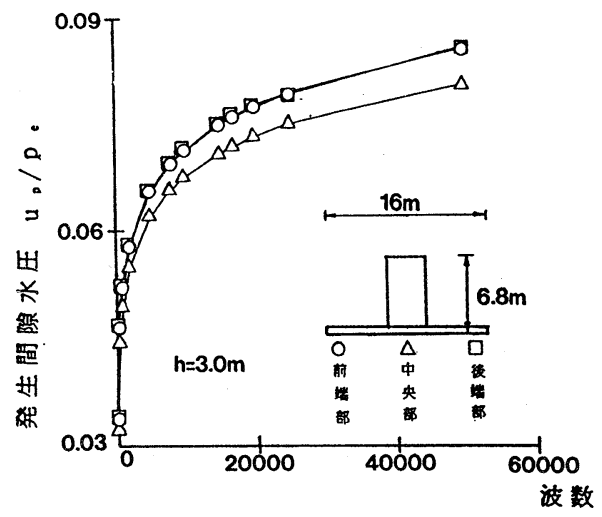

図-14 発生間隙水圧と波数の関係

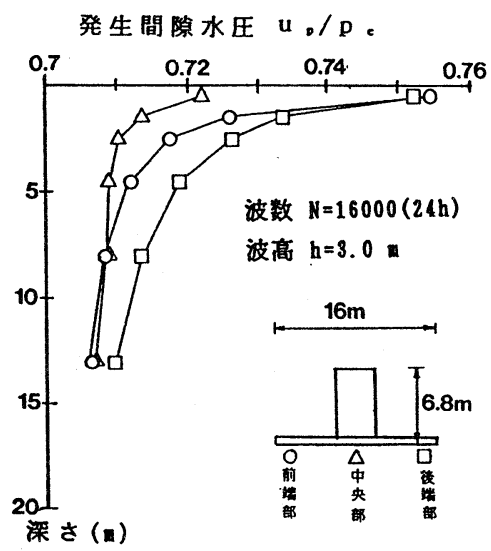

図-15 発生間隙水圧と深さの関係

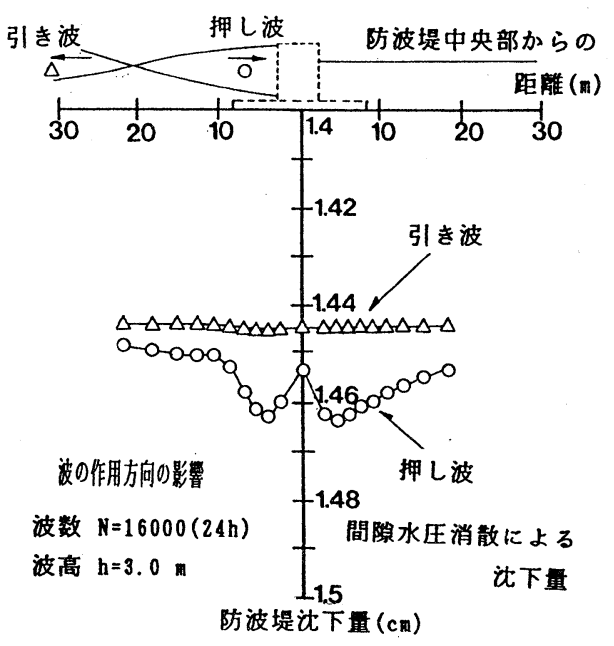

図-16 波の作用方向が沈下量に及ぼす影響 
ることが可能となることか ら、沈下が軽減されたと思 われる。今回の解析では、 海底粘土地盤内に発生する 間隙水圧が小さい為に、間 隙水圧の消散に伴う沈下量 は非排水の繰返しに伴う沈 下量に比べるとかなり小さ い值となった。しかし、防 波堤の安定性を考える際に は重要な要因の一つである と考えて、過剩な間隙水圧 の消散にともなう沈下量と 非排水繰返しによる沈下量 との和を全沈下量であると

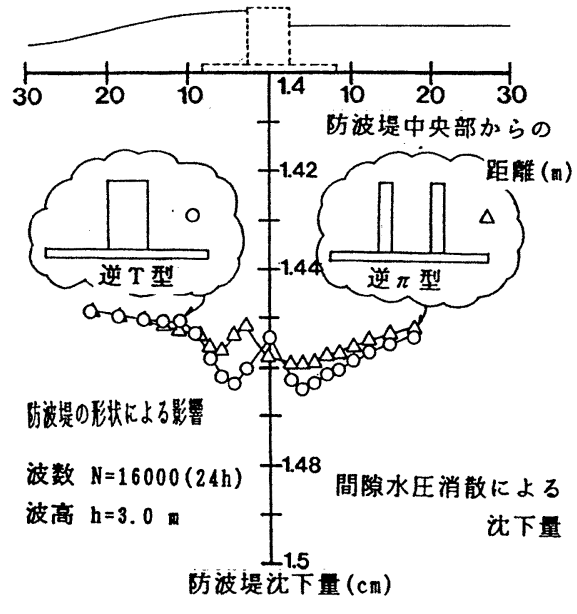

図-17 防波堤の形状が沈下量 に及ぼす影響

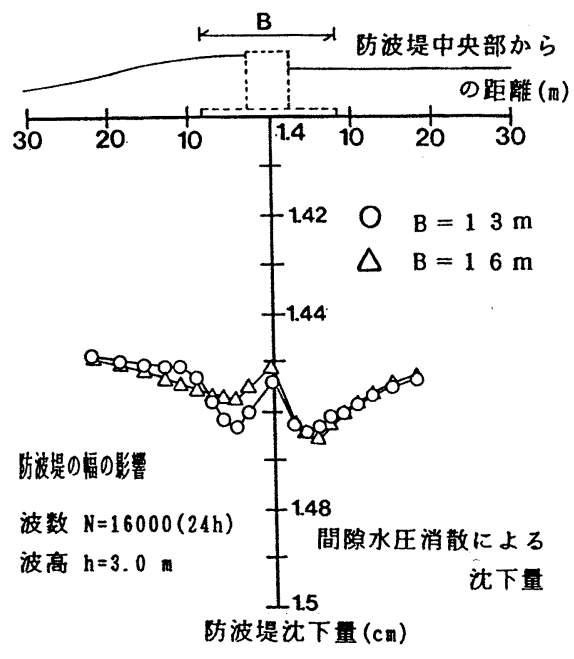

図一-18 防波堤の幅 (B) が沈下量 に及ぼす影響 考元られる。

\section{6 結論}

波浪荷重を受ける海底粘上地盤上の防波是の沈下解析を行なった結果、次のようなことが明らかとなった。 (1)地盤内に発生する最大主応力は防波堤底部の前端部と後端部に応力の集中が起こり、またその大きさとその方 向は押し波時と引き波時では全く異なり、従って、非排水繰返し荷重によるせん断沈下量と発生間隙水圧の消散 による沈下量が異なる結果となった。また、それに伴い防波堤の沈下現象む異り、前端部及び後端部にこのこと が顕著に現れた。従って、押し波、引き波が連続して当たる実際の防波堤下の海底地盤では繰返し応力の大きさ と方向が連続的に変化するために地盤はかなり不安定になると考えられる。また、最大主応力の大きさと方向が 地盤の沈下量、発生間隙水圧に大きな影響を与えることす明らかとなった。

(2)防波堤の沈下量は、防波堤の幅, 形状などにさまざまな影響を受け、沈下の様子す変化する。これは、防波堤 形状の変化が地盤内に発生する最大主応力の大きさと方向を変化させるために生じると考えられ、今回の解析結 果では逆 $\pi$ 型で底部の広い防波堤の安定性が最むよいと思われる。

(3) 防波堤底部の発生間隙水圧は、深度が深くなるにつれて小さくなるが、後端部の方が地中深くまで発生してい る。それにもかかわらず、防波堤前端部の方が大きい沈下量を示したのは、防波堤前端部直下の最大主応力及び 発生間隙水圧の大きさが後端部に比べると大きいためである。また、防波堤の沈下量及び発生間隙水圧の量は波 の波数に影響されるため、波浪荷重を受ける地盤の沈下解析を行う際に波の周期により波数を決定するときは傎 重を期する必要がある。また、発生間隙水圧の消散に伴う沈下量は非排水の繰返しせん断による沈下量に比べる と小さい結果となったが、防波堤の安定性を考える際に重要な要因であることに変りはない。

\section{参考文献}

(1) Yasuhara, K., et al. (1991):Wave-induced pore pressure and deformationin seabed clay, Proc., GE0-COAST' 91, Yokohama, Vol.1,pp.667-672. (2)安原ら(1991): 波浪荷重をうける軟弱地盤上防波堤の沈下解析、土 木学会第 46回年次学術講演会講演概要集,第 3 部門、pp. 240-241. (3) Hyodo, M., et a1.（1988): Analytical procedure for evaluating pore-water pressure and deformation of saturated clay ground subjected to traffic loads, Proc. 6th Int. Conf. Num. Meth. in Geomech., Innsbruck, pp. 653-658. (4)兵動ら (1990): 繰返し 荷重を受ける初期せん断応力下の飽和砂の間隙水圧及び残留変形の予測、第 8 回日本地震工学シンポジュウム論 文集, pp. 739-744. (5) 兵動ら (1992): 繰返しせん断を受ける粘土の間隙水圧および変形の評価, 第26回土質工学研究 発表会概要集、pp.787-790. (6) Yasuhara, K., et al. (1991):Cyclic-induced settlement in soft clays, Proc. 10 th ECSMFE Conf.,Florence, Vol.1,pp.887-890.(7)兵動ら (1990): 繰返し荷重をうける粘土の変形特性、第42回 平成2年度土木学会中国四国支部研究発表会講演概要集, pp 310-311. (8)安原ら (1990): 繰返し荷重をうける異方圧 密粘土の変形特性, 土木学会第45回年次学術講演会講演概要集, 第 3 部門、pp. 710-711. (9)合田 (1973): 防波堤の設 計波圧に関する研究,「港湾技術研究所報告」，vo1.12, No.3,pp31-38. (10)Yasuhara, K., et a1. (1991):Postcyclic recompression settlement in clay, Soils and Foundations, Vo1.31, No.1,pp. 83-94. (11)門司ら (1989): 軟弱地盤着定式防波堤の開発について,「海洋開発論文集」,vo1.5,pp. 103-107. (12)A.M. Brit to, M. J.Gunn (1987) : Critical State Soil Mechanics via Finite Elements, Ellis Horwood Limited. 